\title{
НАИОГООБАОЖЕНИЕ УЧАСТНИКОВ
}

\section{ВНЕШНЕЭКОНОМИЧЕСКОЙ АЕЯТЕ АЬНОСТИ}

Балаева А.А.

\section{К ВОПРОСУ СОЗААНИЯ ОСОБЫХ ЭКОНОМИЧЕСКИХ ЗОН В ПРИГРАНИЧНЫХ РАЙОНАХ РФ}

\begin{abstract}
Аннотация. Объектом и предметом исследования является необходимость создания особых экономических зон в приграничных районах РФ. Приграничные территории имеют особо важное значение для любого государства, они играют ключевую роль во внешней политике, безопасности государства и внешнеэкономических связях. Автор рассматривает такие вопросы, как резкое возрастание значения приграничных территорий как зон контакта с внешним миром в условиях миберализации внешнеэкономической деятельности, необходимость создания на их территориях особыхэкономических зон. Исторически в России весь пояс приграничных территорий является менее развитым и экономически депрессивным, чем схожие по уровню освоенности глубинные территории. Распад СССР и появление в России новых приграничных территорий усугубило это положение. И с этих позиций особое внимание уделяется механизму зачисления таможенных сборов, с иелью экономического роста этих территорий. Изучение вопроса создания особых экономических зон в приграничных районах Российской Федерачии основывалось на методах научного анализа и синтеза. Вклад в исследование выбранной темы - это принятие концепции создания особыхэкономических зон в приграничных районах $Р \Phi$, икакследствие, сочиально-экономическое развитие субъектов РФ, примыкающих к государственной границе $Р \Phi$, за счет пропориионального распределения средств таможенных сборов, сохранение и развитие производительных сил, освоение природных ресурсов, привлечение в приграничные районы российские и иностранные инвестичии, снижение сочиально-экономической ассиметрии субъектов РФ, что и определяет научную новизну работы.
\end{abstract}

Ключевые слова: приграничные территории, особые экономические зоны, экономический потенциал, граница РФ, экономическое развитие, геополитическая значимость, начиональная экономика, приграничный регион, субъекты $Ф$, стимулирующий фактор. 
$\Pi$ риграничные территории имеют особо важное значение Амя мюбого госуАарства, они играют кмючевую роль во внешней политике, безопасности госуАарства и внешнеэкономических связях. В условиях миберализации внешнеэкономической деятельности резко возрастает значение приграничных территорий как зон контакта с внешним миром.

Особый интерес в совокупности заАач бюАжетной политики преАставмяет механизм формирования взаимоотношений между федеральными и региональными институтами власти, имеющими совместные границы с Аругими суверенными государствами. Региональным органам власти и управления приграничных субъектов Федерации в условиях ограниченных природных и финансовых ресурсов приходится решать кроме территориальных задач также вопросы фелерального уровня.

Они кроме социально-экономических заАач реализуют политические, обеспечивая в приграничных зонах безопасность государственной границы, осуществмяют межАународное экономическое и торговое сотруАничество с Аругими государствами, решают миграционные вопросы, реализуют барьерную функцию по отношению к незаконным провозам товаров. Изменение границ, обусловленных распадом СССР, привело к возникновению проблем нового типа, которые требуют государственного регулирования. В хозяйстве новых приграничных регионов России произошли заметные структурные изменения, существенно видоизменились производственные и торговые связи, этнический и качественный состав населения, которые вызвали дополнительные издержки и проблемы ${ }^{1}$.

На этих территориях еще не создана соответствующая инфраструктура, их обустройство связано со значительными затратами финансовых и материальных ресурсов, зачастую их

\footnotetext{
1 Агузарова Ф.С., Бамаева А.А. Проблемы и пути оптимизации налоговой системы России. Вестник Северо-Oceтинского государственного университета имени Коста Аевановича Хетагурова. 2008.T. 3.С 72-77.
}

вынужАены осуществлять сами субъекты РФ. Безусловно, проблема новых границ и приграничных территорий явмяется производной от более высоких по уровню проблем, таких как государственное строительство, макроэкономическая политика, внешняя политика, национальная безопасность, формирование межбюАжетных отношений.

Именно в приграничных регионах эти проблемы наблюдаются в концентрированном виде. Приграничное положение - фактор геополитический, его нельзя изменить, можно Аишь учитывать, формируя бюАжетную, региональную, налоговую, кредитную и внешнеэкономическую политику ${ }^{2}$. Но, несмотря на ту важную роль, которую выполняют приграничные регионы как на общегосударственном, так и на территориальном уровне, проблема их самодостаточности, финансового обеспечения, механизм формирования федеративных и межбюАжетных отношений межАу Федерацией и приграничными субъектами РФ явмяются недостаточно исслеАованными и неполно учитываются при формировании бюАжетной политики госуАарства. Характер приграничных отношений опредемяется тремя составцяющими: отношениями на уровне госуАарств, исходящими из общенациональных интересов; геополитической значимостью приграничного региона в национальной экономической и политической системе; межгосударственными «прямыми» связями межАу сопредельными приграничными территориями, определяемыми региональными администрациями, исходящими из своих мокальных интересов и возможностей.

Основной проблемой при разработке приграничной политики является выдемение объективной приграничной полосы. Аругим параметром приграничной территории явмяется насыщенность приграничного пространства,

\footnotetext{
2 Агузарова $\Lambda$.А. Социальная политика депрессивных территорий в условиях модернизации экономики: стратегии и инструменты // Управление экономи-ческими системами: эмектронный научный журнац. 2013. № 54 (6)
} 
которая характеризуется пиотностью и интенсивностью происходящих в нем процессов и явлений. Как правимо, наиболее значительное их проявмение отмечается вблизи границы, по мере удамения от нее они ослабевают, утрачивают свою приграничную специфику.

Исторически в России весь пояс приграничных территорий явмяется менее развитым и экономически Аепрессивным, чем схожие по уровню освоенности глубинные территории. РаспаА СССР и появмение в России новых приграничных территорий усугубило это поможение, поскольку из 85 субъектов РФ более половины явмяются приграничными. Социамьные и экономические проблемы приграничных территорий значите ьно острее, чем в среАнем по стране, уровень безработицы в 1,5-2 раза выше, чем в целом по России, а Аоля приграничных территорий в экспортном потенциаме страны составцяет не более $3 \%$. В результате вышеперечисленных факторов во многих приграничных территориях наблюдается отток труАоспособного насемения.

Выполняя функции «Ворот страны», приграничные территории практически не получают от государства возмещения за дополнитемьные расходы на подАержку, функционирование, экомогический ущерб, содержание и развитие транспортных коммуникаций приграничных территорий ${ }^{1}$.

Следует отметить, что в налоговых и таможенных кодексах федеративных государств мира поступиение всей массы таможенных пошиин и сборов в централизованный феАеральный бюАжет является анахронизмом, сохранившийся в России со времен крепостного права, что не соответствует современным правовым и экономическим нормам стран, придерживающихся принципов Аемократии и открытой рыночной экономики.

Цемями созАания особых экономических зон в приграничных районах Российской Фе-

\footnotetext{
1 Агузарова $\Lambda$.А. Социальная политика депрессивных территорий в условиях модернизации экономики: стратегии и инструменты // Управление экономи-ческими системами: электронный научный журнал. 2013. № 54 (6).
}

Аерации явмяются социамьно-экономическое развитие субъектов Российской ФеАерации, примыкающих к государственной границе Российской Федерации, за счет более пропорционального распределения среАств таможенных сборов, сохранение и развитие производительных сил, освоение природных ресурсов, привлечение в приграничные районы Российской Фелерации российских и иностранных инвестиций, созАание благоприятных условий Аля социально-экономического развития и снижение социацьно-экономической асимметрии субъектов Российской ФеАерации, граничащих с госуАарственной границей Российской ФеАерации.

Инициатива созАания особых экономических зон в приграничных районах Российской Фелерации Аолжна приналмежать субъектам Российской ФеАерации, территория которых граничит с госуаарственной границей Российской ФеАерации.

Решение о создании особых экономических зон в приграничных районах Российской Федерации вправе приниматься Правительством Российской Федерации по согласованию с органами законодательной и исполнительной власти соответствующего субъекта Российской Федерации.

В связи с тем, что важнейшей цемью созАания особых экономических зон в приграничных районах РФ является социацьно-экономическое развитие субфедерамьных образований, примыкающих к государственной границе, то необхоАимо более пропорциональное распределение средств таможенных сборов. В противовес существующей практике $100 \%$ поступления этих видов сборов в Фелеральный бюАжет, целесообразно применение иного способа распредемения, а именно: в федерамьный бюАжет Российской Федерации Аолжно поступать 70 процентов суммы таможенных сборов и пошлин, взимаемых в приграничных районах Российской Фелерации. В бюАжет же субъекта Российской ФеАерации, на территории которого находится особая экономическая зона, Аолжно поступать 30 процентов таможенных пошиин и сборов, взимаемых на этих территориях. Это позволит 
Увеличить Аоходную часть региональных бюАжетов, уменьшить их Аотационность, что, в конечном счете, повысит социально-экономический уровень развития приграничных территорий.

ОАнако, в случае не Аостижения цемей и невыполнения задач развития регионов, предусмотренных созАанием особых экономических зон, а также несоответствия функционирования особых экономических зон в приграничных районах Российской Федерации интересам Россий- ской Федерации, возможна миквиАация особых экономических зон в приграничных районах Российской Федерации.

В этом скучае Правительство Российской Федерация Аолжно устанавливать сроки миквидации особых экономических зон в приграничных районах Российской Федерации с соблюдением межАународных договоров Российской Федерации и законодательства Российской Федерации.

\section{БИБАИОГРАФИЯ}

1. Агузарова $\Lambda$.А. Социальная политика депрессивных территорий в условиях модернизации экономики: стратегии и инструменты // Управление экономи-ческими системами: эмектронный научный журнац. 2013. № 54 (6).

2. Агузарова Ф.С., Балаева А.А. Проблемы и пути оптимизации налоговой системы России. Вестник Северо-Осетинского государственного университета имени Коста $А$ вановича Хетагурова. 2008.Т. 3.С 72-77.

3. Агузарова Ф.С. Об изменениях российского налогового законодательства//Финансы и креАит. 2014. № 21. С. 46-51.

4. Балаева А. А. Воздействие инвестиционного процесса на воспроизводственный потенциал региона (на примере Республики Северная Осетия-Алания) диссертация на соискание ученой степени кандидата экономических наук/ Ростов-на-Аону, 1999

5. Балаева А.А., Агузарова Ф. С., Азодзиков М. Р. Актуацьные проблемы налогообложения и основные пути их решения. Вестник Северо-Осетинского государственного университета имени Коста Аевановича Хетагурова. 2008. Т. 4. С.115-118.

6. Балаева А. А., Моргоева А.Х. Налоговое администрирование: взгляд в будущее.Налоги и намогообложение. 2014. № 2. c.174-183.DOI: 10.7256/1812-8688.2014.2.11361

7. Балаева А.А. Экономическое развитие региона: современный аспект (на примере Республики Северная Осетия-А^ания.Право и инвестиции. 2013. № 3-4. с. 26-28

8. Аолгих И. П., Черняев Г.М. О юридической стороне национального вопроса // NB: Вопросы права и политики. —2014._-1._ C. 45-53. DOI: 10.7256/2305-9699.2014.1.10788. URL: http://www.e-notabene.ru/lr/article_10788.html

9. Винник Н. В. Вопросы местного значения как гарантия организационной самостоятельности местного самоуправления // ААминистративное и муниципальное право._2013. - 9.— С. 874-877. DOI: $10.7256 / 1999-2807.2013 .9 .9544$.

10. Нарутто С. В. К вопросу об изменении государственной границы // NB: ААминистративное право и практика администрирования. - 2013. - № 12. - C.35-50. DOI: 10.7256/23069945.2013.12.10698. URL: http://e-notabene.ru/al/article_10698.html

11. Павлов П.В. Приграничная торговмя как часть приграничного сотрудничества России с иностранными государствами: проблемы административно-правового регукирования // NB: ААминистративное право и практика аАминистрирования. - 2013.-№ 2.- C.1-71. DOI: 10.7256/2306-9945.2013.2.607. URL: http://e-notabene.ru/al/article_607.html

12. А.Н. Чернышев. Юридическая природа международной аренды государственной территории.. / / Международное право и международные организации / International Law and International Organizations. - 2010.—№ 3. 
13. М.В.Забелина. Границы субъектов Российской Федерации: понятие, статус, функции, правовое закрепление. // Право и политика._2013.—№ 1.— С. 18-26. DOI: 10.7256/18119018.2013.01.

14. Aguzarova L.A., Aguzarova F. S. REGIONAL PECULIARITIES OF FORMATION OF NEW ECONOMIC CONTENT OF THE LABOR POTENTIAL AS A FACTOR OF MODERNIZATION//Наука и человечество. 2013. T. 1. № 2. С. 216-226

\section{REFERENCES (TRANSLITERATED)}

1. Aguzarova L.A. Sotsial'naya politika depressivnykh territorii v usloviyakh modernizatsii ekonomiki: strategii i instrumenty // Upravlenie ekonomi-cheskimi sistemami: elektronnyi nauchnyi zhurnal. 2013. № 54 (6).

2. Aguzarova F. S., Balaeva D. A. Problemy i puti optimizatsii nalogovoi sistemy Rossii. Vestnik SeveroOsetinskogo gosudarstvennogo universiteta imeni Kosta Levanovicha Khetagurova. 2008.T.3.S 72-77.

3. Aguzarova F. S. Ob izmeneniyakh rossiiskogo nalogovogo zakonodatel'stva//Finansy i kredit. 2014. № 21. S. 46-51.

4. Balaeva D. A. Vozdeistvie investitsionnogo protsessa na vosproizvodstvennyi potentsial regiona (na primere Respubliki Severnaya Osetiya-Alaniya) dissertatsiya na soiskanie uchenoi stepeni kandidata ekonomicheskikh nauk/ Rostov-na-Donu, 1999

5. Balaeva D.A., Aguzarova F. S., Dzodzikov M. R. Aktual'nye problemy nalogooblozheniya i osnovnye puti ikh resheniya. Vestnik Severo-Osetinskogo gosudarstvennogo universiteta imeni Kosta Levanovicha Khetagurova. 2008. T. 4. S.115-118.

6. Balaeva D. A., Morgoeva A. Kh. Nalogovoe administrirovanie: vzglyad v budushchee.Nalogi i nalogooblozhenie. 2014. № 2. s.174-183.DOI: 10.7256/1812-8688.2014.2.11361

7. Balaeva D.A. Ekonomicheskoe razvitie regiona: sovremennyi aspekt (na primere Respubliki Severnaya Osetiya-Alaniya.Pravo i investitsii. 2013. № 3-4. s. 26-28

8. Dolgikh I. P., Chernyaev G.M. O yuridicheskoi storone natsional'nogo voprosa // NB: Voprosy prava i politiki._2014.—1.—C. 45-53. DOI: 10.7256/2305-9699.2014.1.10788. URL: http:// www.e-notabene.ru/lr/article_10788.html

9. Vinnik N. V. Voprosy mestnogo znacheniya kak garantiya organizatsionnoi samostoyatel'nosti mestnogo samoupravleniya // Administrativnoe i munitsipal'noe pravo._2013. -9. - C. 874877. DOI: 10.7256/1999-2807.2013.9.9544.

10. Narutto S. V. K voprosu ob izmenenii gosudarstvennoi granitsy // NB: Administrativnoe pravo i praktika administrirovaniya. - 2013. — № 12. - S.35-50. DOI: $10.7256 / 2306$ 9945.2013.12.10698. URL: http://e-notabene.ru/al/article_10698.html

11. Pavlov P. V. Prigranichnaya torgovlya kak chast» prigranichnogo sotrudnichestva Rossii $s$ inostrannymi gosudarstvami: problemy administrativno-pravovogo regulirovaniya // NB: Administrativnoe pravo i praktika administrirovaniya. - 2013. — № 2. - S.1-71. DOI: 10.7256/2306-9945.2013.2.607. URL: http://e-notabene.ru/al/article_607.html

12. D. N. Chernyshev. Yuridicheskaya priroda mezhdunarodnoi arendy gosudarstvennoi territorii.. // Mezhdunarodnoe pravo i mezhdunarodnye organizatsii / International Law and International Organizations. - 2010.—№ 3.

13. M.V. Zabelina. Granitsy sub"ektov Rossiiskoi Federatsii: ponyatie, status, funktsii, pravovoe zakreplenie. // Pravo i politika._2013.—№ 1.—C. 18-26. DOI: 10.7256/1811-9018.2013.01.

14. Aguzarova L.A., Aguzarova F. S. REGIONAL PECULIARITIES OF FORMATION OF NEW ECONOMIC CONTENT OF THE LABOR POTENTIAL AS A FACTOR OF MODERNIZATION//Nauka i chelovechestvo. 2013. T. 1. № 2. S. 216-226 